\title{
Abl protein-tyrosine kinase selects the Crk adapter as a substrate using SH3-binding sites
}

\author{
Ruibao Ren, Zheng-Sheng Ye, and David Baltimore ${ }^{1}$ \\ The Rockefeller University, New York, New York 10021 USA
}

\begin{abstract}
To understand the normal and oncogenic functions of the protein-tyrosine kinase Abl, the yeast two-hybrid system has been used for identifying proteins that interact with it. One interacting protein is Crk-I, an SH3/SH2-containing adapter protein that was originally identified as the oncogenic element in the avian sarcoma virus CT10. Direct interaction between the Crk-I SH3 and Abl at novel, $\sim 10$ amino acid sites just carboxy-terminal to the Abl kinase domain occurs in vitro and in mammalian cells. There is a nearby site specific for binding another adapter, Nck, and these sites also bind Grb-2. When bound to Abl, Crk-I was phosphorylated on tyrosine. Thus, the SH3-binding sites on Abl serve as substrate recognition sites for the relatively nonspecific kinase of Abl. In Crk-I-transformed cells, Crk-I associates with endogenous c-Abl and is phosphorylated on tyrosine. The association of Crk and Abl suggests that Abl could play a role in v-Crk and Crk-I transformation and that normal Abl function may be partly mediated through bound adapter molecules.
\end{abstract}

[Key Words: Abl; Crk; Nck; Grb2; SH3; phosphorylation]

Received November 19, 1993; revised version accepted February 22, 1994.

The $a b l$ oncogene was first identified as the oncogenic element in the Abelson murine leukemia virus (for review, see Rosenberg and Witte 1988; Wang 1993). It is also an oncogenic element in the Philadelphia chromosome, a fusion of a portion of the breakpoint cluster region $(b c r)$ gene with $c-a b l$ found first in cells of human chronic myelogenous leukemia (for review, see Daley and Ben-Neriah 1991).

Although all cells contain some c-Abl, the protein may play a particular role in certain developmental events. Drosophila Abl mutants have a disrupted axonal organization and die in the pupal stage of development (Henkemeyer et al. 1990). Mice with a homozygous disruption of the c- $a b l$ gene-either through a null mutation or a deletion of the carboxy-terminal $1 / 3$ of the protein-are variably affected, but some display increased perinatal mortality, runtedness, lymphopenia, and abnormal head and eye development (Schwartzberg et al. 1991; Tybulewicz et al. 1991).

The amino-terminal half of $\mathrm{c}-\mathrm{Abl}$ is similar to that of many Src family kinases in which Src homology regions SH3 and SH2 abut the kinase (Pawson 1988). SH2 and SH3 domains are modular units present in a very large group of proteins (for review, see Mayer and Baltimore 1993; Pawson and Gish 1992). SH2s, 100 amino acids long, bind to short peptide segments containing a phosphorylated tyrosine residue. Frequently, SH2 binding

\footnotetext{
${ }^{1}$ Corresponding author.
}

links activated growth factor receptors to downstream signal transduction proteins (Pawson and Gish 1992). SH3 domains contain $\sim 50-60$ amino acids and mediate protein-protein interactions among signal transduction proteins by binding to proline-containing sites /Cicchetti et al. 1992; Egan et al. 1993; Gout et al. 1993; Li et al. 1993; Liu et al. 1993; Ren et al. 1993; Rozakis-Adcock et al. 1993; Weng et al. 1993).

Although c-Abl is largely nuclear, some is associated with the plasma membrane or with actin filaments (Van Etten et al. 1989, 1993; McWhirter and Wang 1991|. It is different from most tyrosine kinases in having a long carboxyl terminus that is encoded by a single long exon. In this region of $>600$ amino acids, there is a DNAbinding domain, an actin-binding domain, and a nuclear localization signal (Jackson and Baltimore 1989; Van Etten et al. 1989; Wang 1993). The complexity of c-Abl structure and localization in cells suggests that it may either fulfill multiple cellular functions or that it integrates multiple events. Overproduction of c-Abl does not result in cell transformation or elevated tyrosine phosphorylation in cells, suggesting that the c-Abl proteintyrosine kinase activity is tightly controlled in vivo (Franz et al. 1989; Jackson and Baltimore 1989). Instead, overproduction leads to inhibition of cell growth during $\mathrm{G}_{1}$, suggesting that c-Abl can interact with the machinery of cellular growth control (Jackson et al. 1993a). In contrast to $\mathrm{c}-\mathrm{Abl}$, transforming variants of $\mathrm{Abl}$ are largely cytoplasmic and their kinase activity is constitutively activated (Franz et al. 1989; Jackson and Baltimore 
1989; Van Etten et al. 1989; Jackson et al. 1993b; Muller et al. 1991; Goga et al. 1993).

One way to develop a better understanding of the normal and oncogenic functions of $\mathrm{Abl}$ is to look for proteins that regulate $\mathrm{c}-\mathrm{Abl}$ or are regulated by it. In this study the entire carboxy-terminal half of $\mathrm{Abl}$ was used as a bait to screen a HeLa cDNA expression library using the yeast two-hybrid system (Fields and Song 1989; Zervos et al. 1993). One clone isolated was a fragment of the Crk-I protein, an SH2- and SH3-containing adapter that was originally identified as the oncogenic element of avian sarcoma virus CT10 (Mayer et al. 1988). Crk-I and Abl interaction occurs in vitro and in mammalian cells and, when bound to Abl, Crk-I is phosphorylated on tyrosine. Binding is a consequence of short, linear peptide sequences in $\mathrm{Abl}$ that bind to $\mathrm{SH} 3$ regions of Crk. A site for binding the SH3-containing Nck molecule was also found. These studies show that $\mathrm{SH} 3$ can be a binding region for a kinase substrate, extend our knowledge of $\mathrm{SH} 3$ binding-specificity, suggest that $\mathrm{Abl}$ may play a role in Crk transformation, and that c-Abl may use adapter molecules in its normal function.

\section{Results \\ Proteins that interact with the Abl carboxy-terminal region}

A yeast two-hybrid system was used to identify proteins that interact with c-Abl. The two-hybrid system, originally described by Fields and Song (1989), depends on a transcriptionally derived signal for identification of a gene encoding a protein that interacts with a protein of interest. One hybrid consists of a DNA-binding domain fused to the protein of interest, and the other consists of a transcriptional activation domain fused to a cDNA library. The two-hybrid system used in this study was developed by R. Brent and colleagues (Zervos et al. 1993).

For identifying proteins that interact with the carboxyterminal half of c-Abl (AblC'), a cDNA fragment encoding amino acids 545-1149 of c-Abl was cloned in-frame into the pEG202 vector so it would be made as a fusion protein with the LexA DNA-binding domain (LexA/ AblC'). The LexA/AblC'-encoding plasmid was transformed into yeast EGY48 along with a reporter plasmid that contains the $\beta$-galactosidase gene under LexA-operator control, LexAop-lacZ; the yeast genome also contained an integrated LexAop-LEU2 reporter gene. The expression of the LexA/AblC' fusion protein was confirmed by Western blot analysis using PEX4 anti-Abl antibody (data not shown). Although the yeast contained LexA-controlled genes for synthesis of $\beta$-galactosidase and the $L E U 2$ protein, neither gene was expressed, indicating that the $\mathrm{AblC}^{\prime}$ region provided no transcriptional activating activity.

To identify proteins that interact with $\mathrm{AblC}^{\prime}$, we used a HeLa cDNA library cloned into a conditional expression vector pJG45. In the presence of galactose but not glucose, this vector produce cDNA-encoded proteins fused to an epitope tag, a nuclear localization sequence, and an acidic transcription activation domain. Five million library transformants were plated onto five galactose-Leu selection plates. Colonies that were prototrophic for leucine were replica-plated onto X-gal plates, where $\beta$-galactosidase-producing colonies turn blue. About 100 galactose-dependent, blue colonies were picked, of which 10 were analyzed further in this study. These clones represent $\sim 500,000$ library transformants screened.

The 10 library cDNA plasmids were isolated through genetic selection in Escherichia coli. To test whether the library cDNAs truly encoded proteins that interacted specifically with $\mathrm{AblC}^{\prime}$, the library plasmids were cotransformed back into yeast with vectors that produced either the LexA-binding domain alone or the binding domain fused to the entire c-Abl or $\mathrm{AblC}^{\prime}$. Nine of the clones produced $\beta$-gal activity only when $\mathrm{c}-\mathrm{Abl}$ or $\mathrm{AblC}^{\prime}$ was present (Table 1), suggesting that these cDNAs encode proteins that interact with the carboxyterminal half of c-Abl. The remaining one clone was active even when cotransformed with the LexA DNAbinding domain alone, indicating that this clone did not encode a c-Abl-interacting protein.

\section{Crk cDNA identified}

DNA sequence analysis revealed that the nine c-Ablinteracting clones identified by the two-hybrid screen belonged to three genes. The DNA sequences were compared with sequences from GenBank. Two of them (clone A, representing six independent clones, and clone $C)$ were found to be novel genes. The DNA sequence of clone $B$, representing 2 of 10 primary clones, was identical to part of the human proto-oncogene Crk-I cDNA (Fig. 1).

The Crk oncogene was originally isolated as the oncogenic element of avian retrovirus CT10 (Mayer et al. 1988) and ASV-1 (Tsuchie et al. 1989). The human c-Crk proto-oncogene encodes two proteins, Crk-I and Crk-II, through alternative splicing pathways (Matsuda et al. 1992). Crk-I and Crk-II proteins are adapter molecules containing primarily $\mathrm{SH} 2$ and $\mathrm{SH} 3$ domains: Crk-II has one $\mathrm{SH} 2$ and two SH 3 domains; Crk-I lacks the carboxy-

Table 1. Clones interacting with carboxy-terminal portion of $A b l$ in yeast two-hybrid system

\begin{tabular}{|c|c|c|c|c|}
\hline \multirow[b]{2}{*}{ Clone } & \multirow[b]{2}{*}{$\begin{array}{l}\text { Frequency } \\
\text { (in } 5 \times 10^{5} \\
\text { transformants) }\end{array}$} & \multicolumn{3}{|c|}{$\beta-G a l$ activity in yeast ${ }^{a}$} \\
\hline & & $\begin{array}{l}\text { with } \\
\text { pEG202/ } \\
\text { AblC' }^{\prime}\end{array}$ & $\begin{array}{l}\text { with } \\
\text { pEG.202/ } \\
\text { Abl }\end{array}$ & $\begin{array}{l}\text { with } \\
\text { pEG202 }\end{array}$ \\
\hline A & 6 & + & + & - \\
\hline B & 2 & + & + & - \\
\hline $\mathrm{C}$ & 1 & + & + & - \\
\hline $\mathrm{D}$ & 1 & + & + & + \\
\hline
\end{tabular}

${ }^{a} \beta$-Gal activity in yeast was detected in X-gal plates. Entries indicate the presence or absence of blue color with transformants. 


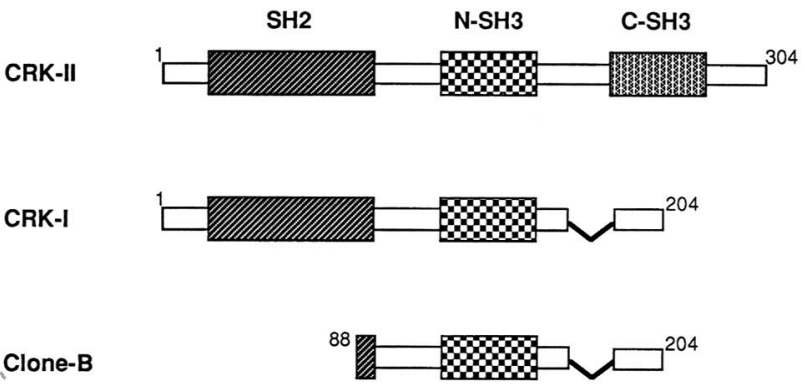

Figure 1. Schematic representation of the c-Abl-interacting Crk protein identified by genetic screening. The domain structures of human Crk-I and Crk-II (Matsuda et al. 1992) are compared with the primary structure of clone $B$ found to interact in the two-hybrid screen with Abl.

terminal SH3 domain. The Abl-interacting clone B cDNA lack the sequence encoding the amino-terminal 87 amino acids of $C r k-I$ cDNA, thus producing a partial Crk-I protein from which the $\mathrm{SH} 2$ domain was mostly deleted (Fig. 1). The Crk/Abl interaction therefore appeared to be mediated by the Crk-I SH3 domain (CrkI$\mathrm{SH} 3$ ).

\section{CrkI-SH3 binds C-AbI in vitro}

To examine whether CrkI-SH3 bound Abl directly, an in vitro filter assay was employed. For this assay, the cloned partial Crk-I protein was expressed as a glutathione $S$-transferase fusion protein in $E$. coli (referred as GST/CrkI-SH3). GST/CrkI-SH3 was purified using glutathione-agarose beads, biotinylated as described (Mayer et al. 1991), and used as a probe on filters containing Abl protein.

The cDNA encoding AblC' was expressed in $E$. coli by cloning it in-frame carboxy-terminal to GST. Crk binding to the GST/AblC' fusion protein was examined following electrophoretic fractionation of crude $E$. coli extracts, transfer to a filter, and probing with biotinylated GST/CrkI-SH3. As revealed by anti-GST antibody /Fig. 2) and PEX4 anti-Abl antibody (data not shown), the GST/AblC' fusion protein expressed in bacteria had an apparent molecular mass of $110 \mathrm{kD}$. However, the majority of the GST/AblC' fusion protein was degraded into polypeptides with various sizes. Because $\mathrm{AblC}^{\prime}$ was tagged with GST, this natural degradation of GST/AblC' facilitated mapping of the binding sites for Crk and other SH3-containing proteins.

The GST/CrkI-SH3 probe bound to the full-length GST/AblC' fusion protein and to a number of its degradation products (Fig. 2). Binding of the GST/CrkI-SH3 probe to GST and the GST probe to the GST/AblC' fusion protein was not detected, indicating that the interaction of GST/CrkI-SH3 and GST/AblC' was through the binding of CrkI-SH3 to AblC'. The GST/AblC' degradation products that bound to CrkI-SH3 were similar to those bound to anti-GST antibody, suggesting that the CrkI-SH3-binding site is located in the amino-terminal portion of $\mathrm{AblC}^{\prime}$.

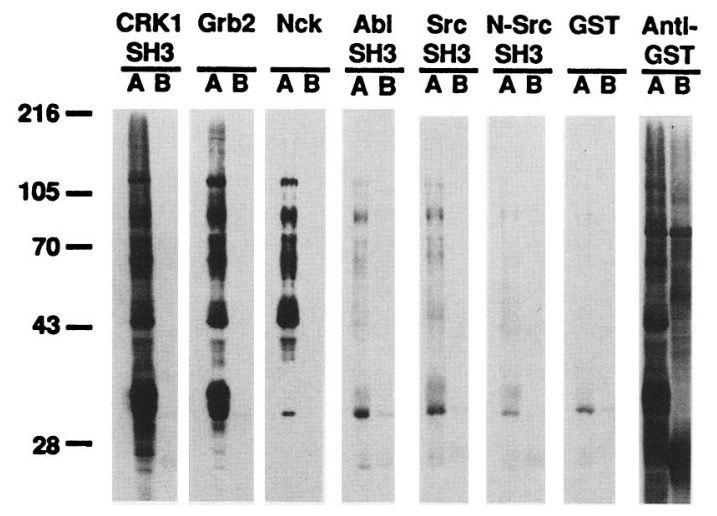

Figure 2. In vitro binding of the c-Abl carboxy-terminal half to various $\mathrm{SH} 3$ domains and $\mathrm{SH} 3$-containing proteins. Proteins from induced lysates of bacteria that expressed the GST-AblC' fusion protein $(A)$ or GST $(B)$ were probed with anti-GST antibody or with biotinylated GST or GST fusion proteins as indicated above each pair of lanes. Numbers (left) represent the molecular size in kilodaltons.

The CrkI-SH3 probe used to examine the Crk-Abl interaction in vitro contained flanking sequences of the SH3 domain. To confirm that the Crk-Abl interaction was through the Crk-I SH3 domain alone, the first SH3 domain of murine c-Crk (Cicchetti et al. 1992) was tested for binding to $\mathrm{AblC}^{\prime}$. The murine Crk SH3 bound to $\mathrm{AblC}^{\prime}$ as effectively as did CrkI-SH3 (data not shown). Both the murine Crk SH3 domain and cloned human CrkI-SH3 could also bind overexpressed full-length c-Abl from NIH-3T3 cells (data not shown).

CrkI-SH3-binding sites are in a region between the Abl kinase domain and its nuclear localization signal

The pattern of CrkI-SH3 binding to the degradation products of the GST/AblC' fusion protein suggested that the SH3-binding site was located in the amino-terminal region of $\mathrm{AblC}^{\prime}$. Sequential deletion analysis of $\mathrm{AblC}^{\prime}$ from its carboxyl terminus mapped the CrkI-SH3-binding site to a 56-amino-acid region (Table 2). In this region there are three proline-containing peptides (APELPTKTR, EPAVSPLLPRK, and APDTPELLHTK) that drew

Table 2. Mapping of the Crk, Nck, and Grb2 SH3-binding sites

\begin{tabular}{lccc}
\hline & \multicolumn{3}{c}{ SH3 binding } \\
\cline { 2 - 4 } GST fusion peptides & CrkI-SH3 & Nck & Grb2 \\
\hline AblC' $(545-1149)^{\mathrm{b}}$ & + & + & + \\
AblC' $\Delta$ Sal $(545-987)$ & + & + & + \\
AblC' $\Delta$ Xho (545-763) & + & + & + \\
AblC'115 (545-659) & + & + & + \\
AblC'56 (551-606) & + & - & + \\
\hline
\end{tabular}

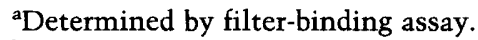

bNumbers indicate the amino acid sequences in type IV c-Abl. 
Ren et al.

our attention because other $\mathrm{SH} 3$ s bind to sites rich in proline (Ren et al. 1993). The binding sites for the CrkISH3 domain were determined by preparing GST fusions of these peptides and expressing them in bacteria. Filterbinding assays showed that CrkI-SH3 bound strongly to peptide APELPTKTR and weakly to peptide EPAVSPLLPRK (Fig. 3A). These two peptides are termed Abl-binding sites for SH3 (AB3-1 and AB3-2). No binding to a third peptide, APDTPELLHTK, was detected (data not shown|. Deletion of the two CrkI-SH3-binding sites abolished the association between Crk-I and c-Abl in cells (see below), indicating that in Abl there are two CrkI-SH3 binding sites located between the Abl kinase domain and the nuclear localization signal (Fig. 3B).

\section{SH2- and SH3-containing adapter proteins Grb2} and Nck bind to $A b l$ in vitro

To examine the specificity of $\mathrm{Crk}-\mathrm{Abl}$ interaction, the binding potential of different $\mathrm{SH} 3$ domains or SH3-containing proteins to $\mathrm{Abl}$ was tested by the filter-binding assay. The Abl-SH3 and Src-SH3 domains bound to GST/AblC' very weakly, but above the signal of GST alone (Fig. 2). No binding was detected for neural-Src (N-Src). According to the binding pattern to the degradation products of GST/AblC', the binding site for AblSH3 seems to be located carboxy-terminal to the Crk and Nck SH3-binding sites. This low affinity interaction may be significant for intramolecular interaction and may play a role in the control Abl kinase activity and/or autophosphorylation.

Interestingly, both of the $\mathrm{SH}$ - and $\mathrm{SH} 3$-containing adapter proteins, Grb2 and Nck, bound to $\mathrm{AblC}^{\prime}$ as strongly as did CrkI-SH3 (Fig. 2). The pattern of Grb2 binding to GST/AblC' and its degradation products was similar to that of CrkI-SH3, suggesting that Grb2-binding sites are located very close to those of CrkI-SH3. However, Nck bound only to the larger degradation products of GST/AblC', indicating that Nck binds in a region carboxy-terminal to the CrkI-SH3 sites.

We mapped the Nck-binding site to a 53-amino-acid region (606-659) (Table 2). The ability of Nck to bind the proline-containing peptide MAPTPPKR (AB3-3) in this region, expressed as a GST fusion protein in bacteria, was tested by the filter-binding assay. Nck bound AB3-3 specifically, but in spite of the three $\mathrm{SH} 3$ domains in Nck, no binding of Nck to AB3-1 and AB3-2 was detected (Fig. 3A). CrkI-SH3 bound very weakly to AB3-3.

Binding of Grb2 to the three AB3s was also examined. Grb2 bound to $A B 3-1$ and $A B 3-3$ strongly and to $A B 3-2$ weakly (Fig. 3A). Because Grb2 contains two $\mathrm{SH} 3$ domains, the binding of different $\mathrm{SH} 3$ domains of Grb2 to $\mathrm{AB} 3 \mathrm{~s}$ was determined using Grb2 mutants. Grb2-N2 is Grb2 with the carboxy-terminal SH3 domain deleted. Grb2-2C is Grb2 with the amino-terminal SH3 domain deleted (Lowenstein et al. 1992). Grb2-N2 bound all
A

\begin{tabular}{|c|c|c|c|c|c|c|}
\hline \multirow{2}{*}{ PROBES } & \multicolumn{5}{|c|}{ GST FUSION PROTEIN } & \multirow{2}{*}{ Anti-GST } \\
\hline & $\begin{array}{c}\text { CRK1 } \\
\text { SH3 }\end{array}$ & Nck & Grb2 & Grb2-N2 & Grb2-2C & \\
\hline LYSATES & ๒灾总总总 & 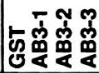 & 㓠总总总 & 鸟灾总总 & 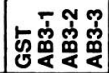 & 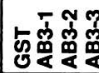 \\
\hline & & - & & & - & \\
\hline
\end{tabular}

3BP2-9

AB3-1

AB3-2

AB3-3

CONSFNSUS

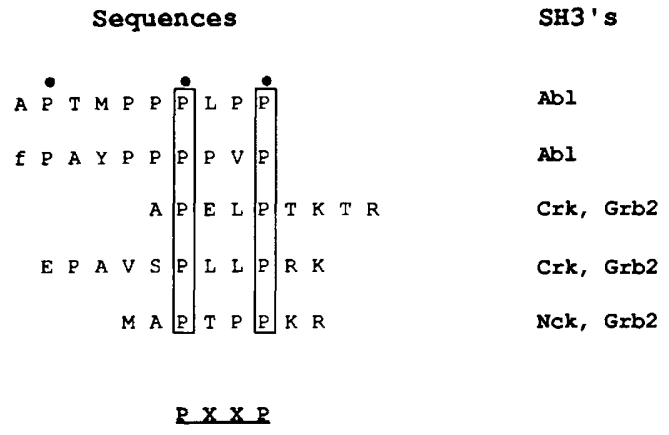

B

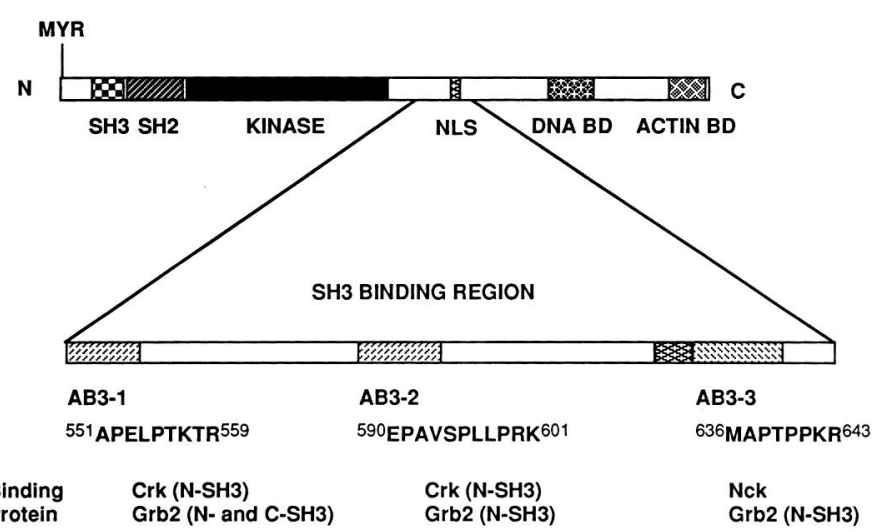

Figure 3. Mapping of the Crk, Nck, and Grb2 SH3-binding sites on c-Abl. $(A)$ Proteins from induced lysates of bacteria expressing the GST fusion peptides (AB3s) were probed with anti-GST antibody or biotinylated GST fusion proteins as indicated. $(B)$ Schematic representation of the domain structure of c-Abl type IV. The amino acid sequences of the Crk, Nck, and Grb2 SH3-binding sites and their locations in c-Abl are indicated. Amino acid residues are represented by single letters. (MYR) Myristoylation site; (NLS) nuclear localization signal; (BD) binding domain. Numbers indicate the positions of amino acids in type IV c-Abl (Ben-Neriah et al. 1986). (C) An alignment of the Abl, Crk, Nck, and Grb2 SH3-binding sites. (O) The amino acid residues essential for the Abl-SH3-binding to 3BP1-10 (Ren et al. 1993). ( $X$ in consensus) The nonconserved amino acids among SH3-binding sites. 
three $A B 3 s: A B 3-3$ was strongest and $A B 3-2$ weakest (Fig. $3 \mathrm{~A})$. The binding of Grb2-N2 to AB3-1 was weaker than that of wild-type Grb2. Grb2-2C bound weakly and only to AB3-1. The different specificities of the two SH3 domains of Grb2 suggested that they may bind Abl cooperatively in a specific orientation.

The locations of the CrkI-SH3, Grb2, and Nck-binding sites in $\mathrm{C}-\mathrm{Abl}$ are shown in Figure 3B.

Two proteins that bind specifically to the Abl-SH3 domain were isolated previously by screening a $\lambda g t 11$ cDNA expression library using the GST/Abl-SH3 fusion protein (Cicchetti et al. 1992). The SH3-binding sites of the two SH3-binding proteins were localized to a 10amino-acid stretch very rich in proline residues (Ren et al. 1993). In the 3BP1 site, proline residues at positions 2, 7 , and 10, were crucial to the binding. A number of SH3binding proteins have been identified since then (Egan et al. 1993; Gout et al. 1993; Li et al. 1993; Liu et al. 1993; Rozakis-Adcock et al. 1993; G. Cheng, S.-Z. Ye, and D. Baltimore, in prep.; K. Alexandropoulos and D. Baltimore, unpubl.). All of the SH3-binding sites have been characterized by multiple proline residues. Although the Abl-SH3- and CrkI-SH3-binding sites are very different in amino acid sequence, they can be aligned with two conserved proline residues spaced by two nonconserved amino acids (Fig. 3C). The Crk, Nck, and Grb2 SH3binding sites share basic amino acids at their carboxyl terminus not found in the Abl sites.

\section{Crk-I associates with both $c-A b l$ and transforming Abl in mammalian cells}

The studies described above demonstrated that truncated Crk, consisting of the SH3 domain and its flanking sequences, interacts with c-Abl both in yeast and in vitro. To determine whether Crk associates with $\mathrm{Abl}$ in vivo, full-length human Crk-I cDNA was cloned by reverse transcriptase (RT)-PCR. For identification purposes, the Crk-I protein was tagged with an influenza virus hemagglutinin (HA) epitope at its amino terminus, producing the HACrkI chimera. The gene for this chimeric protein was subcloned into mammalian expression vector $\mathrm{pGD}$, in which the Moloney leukemia viral long terminal repeat (LTR) directs RNA synthesis.

To study the interaction of Crk and Abl in cells, we first examined a transforming allele of Abl. Human kidney 293 cells were either cotransfected with pGD/ $H A C r k I$ and pGD/c-abl $\triangle \mathrm{XB}$, which encodes SH3-deleted transforming $\mathrm{Abl}$, or transfected with $\mathrm{PGD} / \mathrm{c}$ $a b l \Delta \mathrm{XB}$ alone. After $48 \mathrm{hr}$ the cells were lysed and the lysates were immunoprecipitated with either anti-HA monoclonal antibody (12CA-5), the anti-Abl polyclonal antibody PEX4, or control antibodies. The immunoprecipitates were then subjected to an in vitro kinase assay, using $\left[\gamma-\mathrm{P}^{32}\right]$ ATP to label proteins in vitro. Labeled proteins were separated electrophoretically by SDS-PAGE and detected by autoradiography. A $140-\mathrm{kD}$ phosphorylated protein was precipitated by anti-HA antibody, but not control monoclonal antibody, from cells cotransfected with pGD/HACrkI and pGD/c-abl $\triangle \mathrm{XB}$ (Fig. 4A). This $140 \mathrm{kD}$ protein comigrated with $\mathrm{Abl} \Delta \mathrm{XB}$, as detected by anti-Abl antibody PEX4 (Fig. 4A). Abl $\Delta \mathrm{XB}$ was not precipitated by anti-HA antibody from cells transfected with either pGD/HACrkI (data not shown) or $\mathrm{pGD} / \mathrm{c}-a b l \Delta \mathrm{XB}$ alone. Thus the antibody to HACrkI coprecipitated the Abl protein as detected by its autophosphorylation activity.

A phosphorylated $28-\mathrm{kD}$ protein was precipitated by both anti-HA antibody and anti-Abl antibody, but not control antibody, from cells cotransfected with pGD/ $H A C r k I$ and $\mathrm{pGD} / \mathrm{c}-a b l \Delta \mathrm{XB}$ but not from cells transfected with $\mathrm{pGD} / c-a b l \Delta \mathrm{XB}$ alone (Fig. $4 \mathrm{~A}$ ). This $28 \mathrm{kD}$ protein migrated identically to tyrosine-phosphorylated Crk-I protein as detected by Western blot using anti-HA antibody (data not shown). ${ }^{32} \mathrm{P}$ Incorporation into HACrkI was much less following precipitation by antiHA antibody than by anti-Abl antibody. This may be attributable to a blocking effect of the bound anti-HA antibody.

To determine whether Crk interacts with c-Abl, hu-
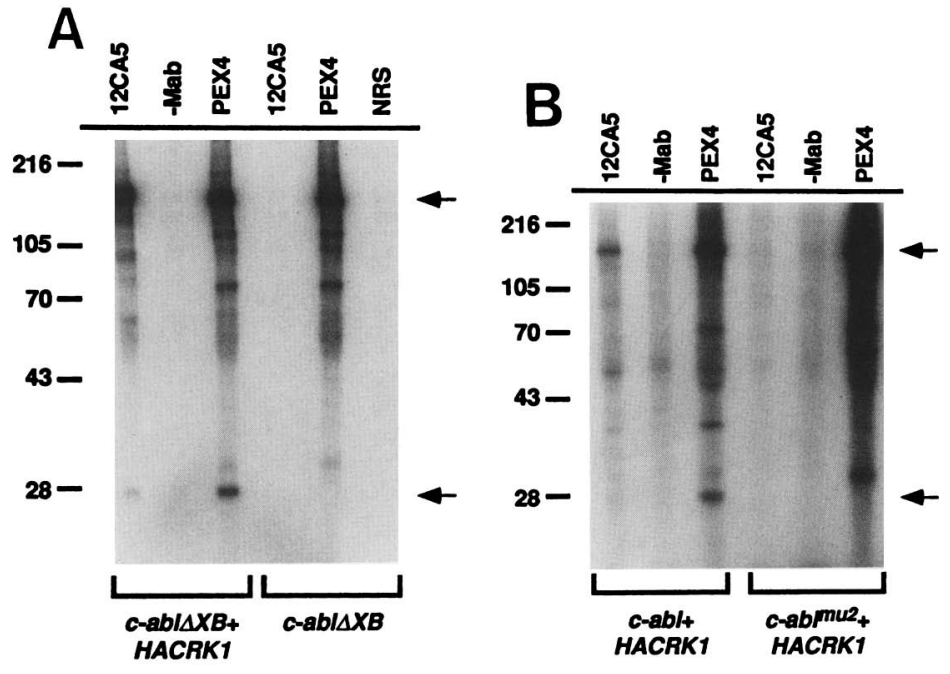

Figure 4. Intracellular association of Crk-I and Abl. $|A|$ Immunoprecipitation (IP) and in vitro kinase analysis of 293 cells expressing the transforming c-Abl $\Delta \mathrm{XB}$ or c-Abl $\triangle X B$ plus HACrkI. (B) IP kinase analysis of 293 cells expressing c-Abl plus HACrkI or c-Abl ${ }^{\text {mu2 }}$ plus HACrkI. IP antibodies are indicated over the lanes. (12CA5) Anti$\mathrm{HA}$ antibody $\left(\operatorname{IgG}_{2 b}\right) ;(-\mathrm{Mab})$ anti-RAG2 monoclonal antibody $\left(\mathrm{IgG}_{2 \mathrm{~b}}\right.$ ) as a control; (PEX4) anti-Abl antibody; (NRS) normal rabbit serum. Gels were exposed to X-ray film overnight. The positions of Abl tyrosine kinase and phosphorylated HACrkI protein on the gels are indicated (right). Numbers (left) represent the molecular size in kilodaltons. 
man kidney 293 cells were cotransfected with pGD/ $H A C r k I$ and $\mathrm{pGD} / \mathrm{c}-a b l$, and ${ }^{32} \mathrm{P}$-labeled, immunoprecipitated proteins were detected after phosphorylation in vitro. As with transforming Abl, labeled Crk-I and c-Abl were specifically precipitated by both anti-HA and anti$\mathrm{Abl}$ antibody (Fig. 4B), indicating that Crk-I associates with c-Abl in cells.

\section{The SH3-binding sites on Abl are needed for Crk interaction in cells}

The in vitro studies mapped the Crk SH3-binding site on $\mathrm{Abl}$ to a region between the Abl kinase domain and its nuclear localization signal. To determine whether the association of $\mathrm{Crk}$ and $\mathrm{Abl}$ in vivo was directly mediated by this interaction, the CrkI-SH3-binding sites were mutated in $\mathrm{c}-\mathrm{Abl}$ by deletion. Mutation of the higher affinity CrkI-SH3 binding site, $\mathrm{AB} 3-1$, gave the $\mathrm{c}-\mathrm{Abl}^{\mathrm{mul}} \mathrm{mu}$ tant Abl protein. Mutation of both CrkI-SH3-binding sites, $\mathrm{AB} 3-1$ and $\mathrm{AB} 3-2$, gave c-Abl ${ }^{\mathrm{mu} 2}$ mutant $\mathrm{Abl}$ protein. The expression and in vitro kinase activity of the mutant Abl proteins were similar to that of c-Abl (Fig. 4B). To examine whether HACrkI interacts with the mutant Abl proteins, they were coexpressed in 293 cells. Immunoprecipitation and in vitro kinase assay showed that HACrkI and c-Abl ${ }^{\mathrm{mul}}$ still form a complex in cells (data not shown). Association of HACrkI and c-Abl ${ }^{\mathrm{mu} 2}$ however, was not detected by immunoprecipitation and kinase assay (Fig. 4B), indicating that Crk-I interacts with $\mathrm{Abl}$ through the CrkI-SH3 domain's binding to the defined sites in Abl.

\section{Crk is phosphorylated on tyrosine upon binding to $A b l$}

The immunoprecipitation studies showed that Crk-I protein and Abl were coprecipitated by both anti-HA antibody and anti-Abl antibody. The Crk-I protein was phosphorylated as shown by ${ }^{32} \mathrm{P}$ incorporation, suggesting that Crk-I is an Abl kinase substrate. To examine whether Crk-I is phosphorylated by Abl kinase in vivo, 293 cells were either transfected with $\mathrm{pGD} / \mathrm{HACrkI}$ or cotransfected with pGD/HACrkI and pGD/c-abl. After $48 \mathrm{hr}$, cells were metabolically labeled with ${ }^{32} \mathrm{P}_{\mathrm{i}}$. ${ }^{32} \mathrm{P}_{\mathrm{i}}$ labeled cells were then lysed, and the lysates were subjected to immunoprecipitation with anti-HA monoclonal antibody. The immunoprecipitates were separated electrophoretically by SDS-PAGE and detected by autoradiography. In cells overexpressing HACrkI alone, it was very weakly phosphorylated and migrated with an apparent molecular mass of $24 \mathrm{kD}$ (Fig. 5A). In cells coexpressing HACrkI and c-Abl, HACrkI was hyperphosphorylated and its electrophoretic mobility was quantitatively shifted to an apparent molecular mass of $28 \mathrm{kD}$ (Fig. 5A). Autophosphorylation of c-Abl in cells was not detectable. Phosphoamino acid analysis demonstrated that the hyperphosphorylated HACrkI contained mainly phosphotyrosine and some phosphoserine (Fig. 5B). The phosphoamino acid(s) in the 24-kD HACrkI from cells not transfected with $\mathrm{c}-\mathrm{Abl}$ could not be detected under this condition.

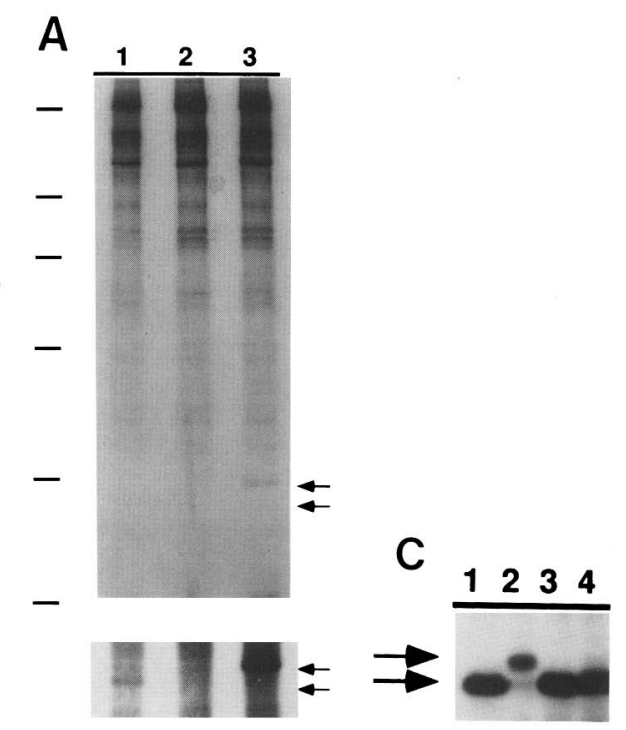

B

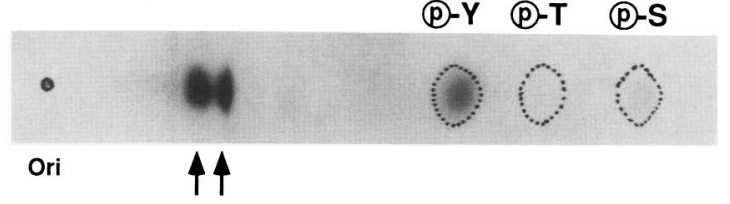

Figure 5. HACrk-I is phosphorylated on tyrosine by c-Abl. $(A)$ Immunoprecipitation of the ${ }^{32} \mathrm{P}$-labeled 293 cells expressing HACrkI (lane 1), c-Abl (lane 2), and HACrkI plus c-Abl (lane 3) with anti-HA antibody. The top and bottom autoradiograph represent short and long exposures of the gel. Positions of molecular size markers of $216,105,70,43,28$, and $18 \mathrm{kD}$ are marked at left from top to bottom, respectively. (B) Phosphoamino acid analysis of HACrkI immunoprecipitated from 293 cells expressing HACrkI plus c-Abl. Positions of the P-Ser, P-Thr, and P-Tyr phosphoamino acid standards are indicated. Arrows indicate incompletely hydrolyzed phosphopeptides. (Ori) Origin of the spotted sample. $(C)$ Western blot analysis with anti-HA antibody of the anti-HA immunoprecipitates from 293 cells expressing HACrkI (lanes 1,3) and HACrkI plus c-Abl (lanes 2,4) in the presence (lanes 1,2 ) or absence (lane 3,4 ) of sodium othorvanadate. The blot was developed with HRP-conjugated goat anti-mouse $\mathrm{IgG}_{2 \mathrm{~b}}$ and enhanced chemiluminescence (ECL, Amersham).

To examine whether the slower migration rate of the hyperphosphorylated HACrkI was attributable entirely to its tyrosine phosphorylation, cells expressing HACrkI or HACrkI plus c-Abl were lysed and immunoprecipitated with anti-HA antibody in the presence or absence of sodium orthovanadate, a compound that was included in all of the analyses described previously to inhibit endogenous tyrosine-specific phosphatases. The immunoprecipitates were then subjected to Western blot analysis with anti-HA antibody. In the presence of vanadate, the HACrkI protein from cells coexpressing HACrkI and c-Abl migrated more slowly than it did in the absence of c-Abl (Fig. 5C, lanes 1,2). In the absence of vanadate, the HACrkI protein migrated similarly whether derived from cells expressing HACrkI alone or HACrkI and c-Abl 
(lanes 3,4). Only the slower migrating HACrkI contained phosphotyrosine, as detected by antiphosphotyrosine antibody (data not shown). These data indicate that the Abl-generated electrophoretic mobility shift of HACrkI in SDS-PAGE is attributable to tyrosine phosphorylation.

Using the mutants of c-Abl described above, we could show that the phosphorylation of Crk depended on its ability to interact with Abl. Compared with wild type (Fig. 6, lane 2), less HACrkI protein was tyrosine phosphorylated in cells coexpressing HACrkI and $\mathrm{c}-\mathrm{Abl}^{\mathrm{mul}}$ (lane 3) and very little phosphorylated form was evident when both CrkI-SH3-binding sites were deleted in $\mathrm{c}-\mathrm{Abl}^{\mathrm{mu} 2}$ (lane 4). The expression of c-Abl and mutant c-Abl proteins in these cells was about equal (data not shown), directly demonstrating that the HACrk/Abl SH3-mediated interaction makes HACrk a substrate for the Abl kinase domain.

\section{Crk-I associates with c-Abl and is phosphorylated in Crk-I-transformed fibroblast cells}

Chicken embryo fibroblasts infected with the avian retrovirus CT10 become rapidly transformed in tissue culture (Mayer et al. 1988). Cells transformed by CT10 virus display elevated tyrosine phosphorylation on a number of proteins (Matsuda et al. 1990; Mayer and Hanafusa 1990a), suggesting that there is a tyrosine kinase involved in v-Crk transformation. Overexpression of human Crk-I, but not Crk-II, leads to transformation of mammalian fibroblasts (Matsuda et al. 1992). To examine whether the endogenous c-Abl is a Crk-I-associated tyrosine kinase in Crk-I-transformed cells, we established an HACrkI-transformed NIH-3T3 cell line /see Materials and methods). In the HACrkI-transformed cells, HACrkI induces and associates with a number of tyrosine phosphorylated proteins typically seen in $\mathrm{v}$-Crk and Crk-I-transformed cells (data not shown; Matsuda et al. 1992). Western blot analysis using anti-Abl monoclonal antibody showed that c-Abl was precipitated by antiHA antibody from a transformed cell line (Fig. 7A, lane 1) but not by an isotype-matched control monoclonal antibody (lane 3). Anti-Abl rabbit antibody PEX4 precipitated more Abl (lane 4), and normal rabbit serum did not precipitate the protein (lane 2). Precipitation of Abl by antiHA antibody was seen in an independent transformed line (data not shown).

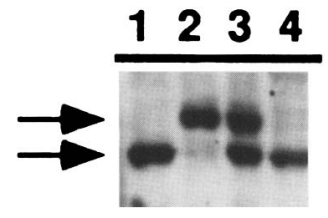

Figure 6. Western blot analysis with anti-HA antibody of the 293 cells expressing HACrkI (lane 1), HACrkI plus c-Abl (lane 2), HACrkI plus c-Abl ${ }^{\mathrm{mu} 1}$ (lane 3), and HACrkI plus c-Abl ${ }^{\mathrm{mu} 2}$ (lane 4). Arrows indicate positions of tyrosine-phosphorylated and non-tyrosine-phosphorylated HACrkI proteins on filter. Developed with $H R P$-conjugated goat anti-mouse $\operatorname{IgG}_{2 b}$ and ECL.

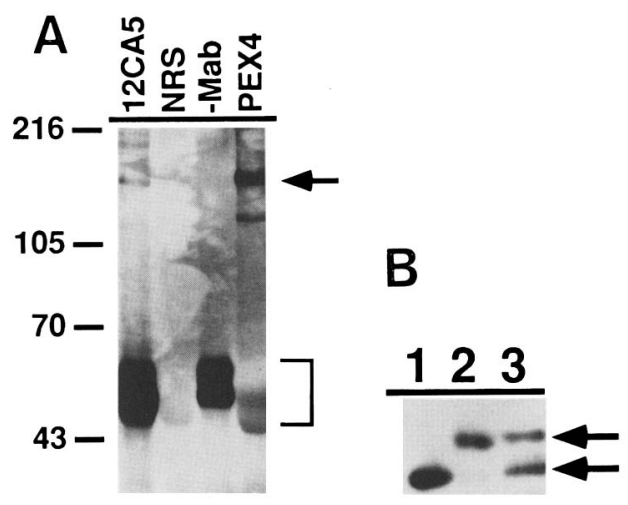

Figure 7. Association of HACrkI with $\mathrm{Abl}$ and phosphorylation of HACrkI in the HACrkI-transformed cells. (A) The HACrkI-transformed cell lysates were immunoprecipitated with antibodies indicated over the lanes (see Fig. 4A). The immunoprecipitates were subjected to Western blot analysis with anti-Abl monoclonal antibody and developed with HRP-conjugated goat anti-mouse IgG and ECL. Arrow indicates the position of the Abl tyrosine kinase; the bracket indicates immunoglobulin heavy chain on the blot. Numbers (left) represent the molecular size in kilodaltons. $(B)$. Western blot analysis with anti-HA antibody of the 293 cells expressing HACrkI (lane 1), HACrkI plus c-Abl (lane 2), and HACrkI-transformed NIH-3T3 cells (lane 3). Arrows indicate positions of tyrosine-phosphorylated and non-tyrosine-phosphorylated HACrkI proteins on filter. Developed with HRP-conjugated goat anti-mouse $\operatorname{IgG}_{2 \mathrm{~b}}$ and ECL.

In 293 cells transfected with both $\mathrm{HACrkI}$ and $\mathrm{Abl}$, we showed that HACrkI is phosphorylated on tyrosine when it can bind to Abl. The phosphorylated HACrkI migrates more slowly than the unphosphorylated form on SDS-PAGE. In HACrkI-transformed cells, the electrophoretic mobility of a portion of HACrkI was shifted to this higher apparent molecular weight (Fig. 7B, lane 3), and this form reacted with antiphosphotyrosine antibody (data not shown). Thus, in Crk-I-transformed cells a portion of Crk-I associates with endogenous c-Abl and is phosphorylated on tyrosine.

\section{Discussion}

Using the yeast two-hybrid screen, in vitro binding assays, and interaction assays in mammalian cells, we have found that $\mathrm{Abl}$ contains selective binding sites for SH3 domains of Crk and Nck. The binding sites for Crk can mediate HACrk phosphorylation, implying that they serve the function of substrate binding sites. This work demonstrates that $\mathrm{SH} 3$ domains are versatile units for bringing together cellular proteins in a highly specific manner, that $\mathrm{SH} 3$ units can serve as substrate binding sites for enzymes, that Abl function must involve previously unsuspected interactions with adapter proteins, and that Crk may function at least partly through $\mathrm{Abl}$.

We reported previously that $\mathrm{SH} 3$ domains can bind with high affinity to target proteins using as binding sites small, linear, proline-rich determinants (Ren et al. 1993). The present study extends that concept by show- 
Ren et al.

ing that many SH3s have binding sites, each with a different specificity not necessarily involving more than two prolines. Thus, $\mathrm{SH} 3$ domains can provide the specificity to mediate aggregation of many highly specific protein complexes. Studies of the interaction of $\mathrm{SH} 3 \mathrm{do}-$ mains on Grb2 with proline-rich sites on Sos protein have also extended the range of action of $\mathrm{SH} 3$ regions (ref. in McCormick 1993). There, it appears that the function of SH3 is to bring the Sos protein to the cell membrane where it can find its substrate Ras. Similarly, SH3 domains were implicated in directing cellular localization of PLC $\gamma$ and Grb2 (Bar-Sagi et al. 1993). The GTPase dynamin binds to and is activated by SH3 domains on other proteins (Gout et al. 1993). Furthermore, we have found recently that SH3 domains on Fyn, Lyn, and Hck can bring these protein-tyrosine kinases to the Btk kinase (G. Cheng, Z.-S. Ye, and D. Baltimore, in prep.). Thus, SH3 binding can apparently serve to bring substrates to enzymes, to organize protein complexes at the cell membrane and probably elsewhere in the cell, and to regulate enzymatic activities. Given the nature of molecules that contain SH3s, the purpose of these interactions must be to facilitate the transmission of signals through the cytoplasm and nucleus of the cell.

The function of the Crk-SH3 interaction with Abl appears to be, at least in part, to bring one or more tyrosines of Crk into the catalytic site of the Abl kinase domain. In vitro studies with the Abl kinase (Foulkes et al. 1985; Frackelton 1985), as well as its extensive phosphorylation of bacterial proteins (Wang et al. 1982), led us to conclude previously that it was a kinase with very little intrinsic substrate specificity. We can now suggest that this relative nonspecificity is a characteristic of the active site but that specificity can be mediated by interactions elsewhere in the molecule. Abl not only has its own $\mathrm{SH} 2$ and $\mathrm{SH} 3$ regions amino-terminal to the $\mathrm{ki}$ nase-the $\mathrm{SH} 2$ having been implicated previously in bringing substrates to the kinase (Mayer and Baltimore, 1994 - but it has the SH3-binding sites carboxy-terminal to the kinase, which capture substrates. In both cases, the substrates would be expected to dissociate from the enzyme relatively slowly compared with dissociation from enzymes that have substrate binding sites as integral parts of their catalytic machinery. This has three consequences: The substrate will stay near the enzyme so that phosphorylation can predominate over dephosphorylation by phosphatases; the enzyme will have a very low turnover number because the substrate will not dissociate easily; and other substrates can also be brought to the enzyme through secondary domain associations. Crk in particular has an SH2 domain that can interact with other proteins, potentially mediating formation of complex, multiprotein complexes. It has been shown previously that the $\mathrm{SH} 2$ domains can mediate complex formation, particularly on receptor protein-tyrosine kinases, and we now must see $\mathrm{SH} 3$ as equally important in such interactions, especially because the $\mathrm{Abl}$ example shows us that one protein can have both an SH3 domain and an SH3-binding site.

The limitation of turnover number caused by separat- ing the catalytic site from the substrate site has an important implication for signal transduction pathways: A signal will only be passed in a limited fashion, with relatively little amplification. By independent evolution of the substrate binding sites in transduction pathways, the extent of signal amplification can be controlled. A similar example is the Raf-Mek interaction, where Raf kinase stably binds its substrate Mek kinase through its carboxyl catalytic domain (Crews and Erikson 1993; Van Aelst et al. 1993).

In cells coexpressing HACrkI and c-Abl, HACrkI was phosphorylated by c-Abl as described; however, autophosphorylation of $\mathrm{c}-\mathrm{Abl}$ in cells was not detected. This observation suggest that $\mathrm{c}-\mathrm{Abl}$ may be activated without autophosphorylation, and the autophosphorylation, often seen in transforming variants of $\mathrm{Abl}$, may provide other signals, for example, recruiting $\mathrm{SH} 2$-containing signaling molecules.

\section{Crk structure and function}

The human $c r k$ proto-oncogene encodes two proteins through alternative splicing (Matsuda et al. 1992). In this study the association of Crk-I and Abl through the SH3 interaction was demonstrated. Crk-II contains the Crk-I SH3 domain, making it likely that Crk-II will also associate with $\mathrm{Abl}$ in cells. Consistent with this possibility, the endogenous Crk-II proteins become phosphorylated on tyrosine in cells overexpressing transforming Abl (B. Mayer, unpubl.). Crk-II is the predominant form of Crk in most cells and differs in having a second SH3 domain of unknown specificity (Matsuda et al. 1992; Tanaka et al. 1993|. Overexpression of human Crk-I leads to transformation of mammalian fibroblasts, whereas Crk-II is not transforming and therefore the second SH3 could serve to modulate the function of the first (Matsuda et al. 1992). Microinjection of Crk-I into PC-12 cells induces neuronal differentiation, whereas Crk-II has a much weaker effect in PC-12 cells (Tanaka et al. 1993), again suggesting that the second SH3 is inhibitory to Crk function. Thus, if Crk-I is a mediator of growth and differentiation events, Crk-II may have a more temperate activity.

\section{Role of the Crk/Abl association in v-Crk transformation}

Avian v-Crk is composed of viral Gag protein fused to a Crk-I-like domain containing one $\mathrm{SH} 2$ domain and one SH3 domain (Mayer et al. 1988). Chicken embryo fibroblasts infected with the avian retrovirus CT10 become rapidly transformed in tissue culture and induce tumors when injected into chickens (Mayer et al. 1988). Although v-Crk protein does not have a tyrosine kinase domain, cells transformed by CT10 virus display elevated tyrosine phosphorylation on a number of proteins (Matsuda et al. 1990; Mayer and Hanafusa 1990a), suggesting that there is a tyrosine kinase involved in v-Crk transformation. Tyrosine kinase activity was found to associate with Crk (Mayer and Hanafusa 1990a), and 
both Crk SH2 and SH3 domains were found to be required for transformation (Mayer and Hanafusa 1990b). The demonstration of Crk and $\mathrm{Abl}$ association in this study indicates that the c-Abl tyrosine kinase is a Crkassociated tyrosine kinase and may play a critical role in Crk transformation.

\section{Binding of other adapter proteins to $A b 1$}

Nck and Grb2 both interact with $\mathrm{Abl}$ in vitro. Nck was originally isolated from a melanoma expression cDNA library (Lehmann et al. 1990). It contains primarily three $\mathrm{SH} 3$ and one SH2 domains and is oncogenic. Overexpression of Nck leads to transformation of mammalian fibroblasts (Chou et al. 1992; Li et al. 1992). Nck is phosphorylated on both tyrosine and serine and threonine in response to epidermal growth factor (EGF), platelet-derived growth factor (PDGF), and nerve growth factor (NGF) stimulation, in response to activation of $\mathrm{T}$-cell receptor and membrane IgM receptor and in $\mathrm{v}$-Src-transformed cells (Chou et al. 1992; Li et al. 1992; Meisenhelder and Hunter 1992; Park and Rhee 1992). It is a common target for many receptor and nonreceptor tyrosine kinases. Nck binds to tyrosine-phosphorylated EGF receptor or PDGF receptor through its SH2 domain (Li et al. 1992). Studies here suggest that Nck associates with c-Abl through one or more of its $\mathrm{SH} 3$ domains. This association may also lead to tyrosine phosphorylation of Nck and could be important for signal transduction as well as Nck transformation.

Grb2 (Lowenstein et al. 1992), also known as ASH, Sem5, or Drk (Clark et al. 1992; Matuoka et al. 1992; Simon et al. 1993) is an SH2- and SH3-containing adapter that links activated protein-tyrosine kinase receptors to the Ras activator protein Sos. Consistent with our in vitro data, Pendergast et al. recently showed that both Grb2 SH3 domains can bind to c-Abl in vitro (Pendergast et al. 1993). The functional significance of this binding is uncertain because Grb2 is involved in other interactions with its SH3 domains, particularly with the Ras activator protein Sos. The Grb2 SH2, however, binds to a tyrosine-phosphorylated site in Bcr-Abl that is critical for transformation (Pendergast et al. 1993), providing the opportunity for a multipoint interaction among these proteins.

The Crk, Nck, and Grb2 SH3-binding sites were mapped close to the nuclear localization signal. The association of these adapter molecules with $\mathrm{Abl}$ may block the translocation of $\mathrm{Abl}$ into the nucleus and, therefore, retain $\mathrm{Abl}$ in cytoplasm. Alternatively, the association of Crk with c-Abl may bring Crk into nucleus. Translocation of proteins in cells is an important mechanism for transducing signals.

$\mathrm{c}$-Abl has one close relative, Arg, that might also be a target for binding by the adapters that bind to Abl. Arg is also a protein-tyrosine kinase with $\mathrm{SH} 2, \mathrm{SH} 3$, and a long carboxy-terminal extension (Kruh et al. 1986). The carboxy-terminal portion of Arg is less homologous to c-Abl than the amino terminus, but the Crk, Nck, and Grb2 SH3-binding sites identified in c-Abl are conserved, sug- gesting that these adapter molecules should also bind Arg.

\section{Characteristics of SH3-binding sites}

The solution and crystal structure of the $\mathrm{SH} 3$ domains of spectrin, Src, Fyn, p85 $\alpha$, and PLC $_{\gamma}$ have been solved (Musacchio et al. 1992; Yu et al. 1992; Booker et al. 1993; Kohda et al. 1993; Koyama et al. 1993; Noble et al. 1993). All of these SH3 domains are formed from five antiparallel $\beta$-strands. The perturbation of resonances by bound proline-rich peptides indicates that the binding site is a hydrophobic surface region of the $\mathrm{SH} 3$ domain that consists of aromatic residues flanked by two charged loops (Booker et al. 1993; Yu et al. 1992).

Like the Abl-SH3-binding sites, the Crk, Nck, and Grb2 SH3-binding sites in c-Abl were mapped to prolinecontaining short stretches of amino acids. The CrkISH3-binding sites were proved to mediate the association of Crk-I and Abl in cells. The specificity of the SH3 interactions is evident. However, is there any common structural motif in the SH3-binding sites that might fit into a conserved element of $\mathrm{SH} 3$ structure? An alignment of the Abl, Crk, Nck, and Grb2 SH3-binding sites shows that two proline residues spaced by two nonconserved amino acids are conserved. The consensus PXXP was also observed among some other SH3-binding sites (Egan et al. 1993; Gout et al. 1993; Li et al. 1993; Liu et al. 1993; Rozakis-Adcock et al. 1993; G. Cheng, Z.-S. Ye, and D. Baltimore, in prep.; K. Alexandropoulos, unpubl.), suggesting that PXXP may serve as a scaffold for the SH3 interaction. The amino acids around these two highly conserved proline residues might then determine SH3binding specificity. For example, the nonconserved sequences amino-terminal to the PXXP consensus, particularly the critical proline at position 2 in the 3BP1 site, may play an important role for Abl-SH3-binding specificity. The basic amino acid(s) carboxy-terminal to PXXP in the CrkI, Grb2, and Nck SH3-binding sites could play a similar role.

\section{Materials and methods}

\section{Cells and antibodies}

293 T cells (Pear et al. 1993) were grown in Dulbecco's modified Eagle medium (DMEM) containing 10\% fetal bovine serum, 100 $\mathrm{U} / \mathrm{ml}$ of penicillin, and $100 \mathrm{mg} / \mathrm{ml}$ of streptomycin. Mouse monoclonal antibody 12CA-5 (Berkeley Antibody Company), anti-Abl monoclonal antibody 24-21 (Oncogene Science), and goat anti-mouse IgG-HRPO and IgG2b-HRPO (Southern Biotechnology Associates, Inc/ were used in this study. Abl-specific PEX4 antiserum was described previously (Konopka et al. 1984). The control monoclonal antibody used was an anti-RAG2 monoclonal antibody (Spanopoulou et al. unpubl.).

HACrkI-transformed cell lines were established by infecting NIH-3T3 cells with an HACrkI retrovirus. The helper-free HACrkI retrovirus was generated by transiently transfecting BOSC-23 cells with pGD/HACrkI as described (Pear et al. 1993). NIH-3T3 cells $\left(2 \times 10^{5}\right)$ infected with $5 \times 10^{5}$ HACrkI retrovirus were transfered into $0.3 \%$ soft agar 2 days after infection. Colonies were picked after 3 weeks. The transformed cells 
Ren et al.

were purified twice. Three independent transformed cell lines were analyzed. All of these cell lines expressed a high level of HACrkI.

\section{DNA constructs}

Plasmid DNAs were grown in E. coli DH5 $\alpha$ and purified by $\mathrm{CsCl}$ centrifugation (Ausubel et al. 1990). DNAs were cleaved with restriction endonucleases under conditions recommended by the manufacturer (Boehringer Mannheim Biochemicals). Restriction fragments were purified by electrophoresis in low-gelling-temperature agarose gels (Ausubel et al. 1990). Ligations were performed according to the instructions of the manufacturer of T4 DNA ligase (Boehringer Mannheim Biochemicals).

For the two-hybrid screen, cDNA fragment encoding the carboxy-terminal portion (amino acid 545-1149) of c-Abl (Ben-Neriah et al. 1986), excised from plasmid pBS/D20 (B. Mayer and D. Baltimore, unpubl.) by BamHI and NotI restriction enzyme digestion, was cloned in-frame into pEG202 vector with an EcoRI-BamHI linker. This plasmid was designated as $\mathrm{pEG} /$ $a b l C^{\prime}$.

For the in vitro SH3-binding assay, the cDNA fragment encoding the carboxy-terminal portion (amino acid 545-1149) of $\mathrm{c}-\mathrm{Abl}$ was cloned in-frame into the pGEX-1ZT vector /modified pGEX-1 $\lambda T$ (Pharmacia) by inserting multiple restriction sites into EcoRI site of pGEX- $\mid \lambda T$ ). pGEX-AblC' $\Delta$ Sal and pGEX$A b l C^{\prime} \Delta X$ ho were constructed by subcloning the BamHI-SalI and $B a m H I-X h o I ~ c D N A$ fragments from $\mathrm{pBS} / \mathrm{D} 20$ in-frame into the pGEX-1ZT vector. A DNA fragment encoding AblC'-115 and $A b l C^{\prime}-56$ was constructed with synthetic oligonucleotidedirected PCR of the c-abl cDNA under the conditions recommended by Perkin-Elmer Cetus. Pfu DNA polymerase /Stratagene) was used for PCR. The PCR reaction was carried out for 15 cycles at $95^{\circ} \mathrm{C}$ for $30 \mathrm{sec}, 55^{\circ} \mathrm{C}$ for $1 \mathrm{~min}$, and $72^{\circ} \mathrm{C}$ for $2 \mathrm{~min}$. Oligonucleotides contain 22 bp of identical sequence for hybridization and a BamHI site (for the sense oligonucleotide) or XhoI site (for the anti-sense oligonucleotide) with four extra base pairs at the $5^{\prime}$ end for stability and recutting efficiency. The PCR fragments were cloned in-frame into the BamHI-XhoI site of the pGEX-1ZT vector. The rest of DNA fragments encoding the peptides $A B 3-1$ to $A B 3-3$ were derived from the synthetic oligonucleotides. The oligonucleotides that were cloned into the BamHI-EcoRI site of the pGEX2T vector contained coding sequences plus $5^{\prime}$-GATCC- $3^{\prime}$ at the $5^{\prime}$ end of the sense strand and $5^{\prime}$-AATT- $3^{\prime}$ at the $5^{\prime}$ end of the anti-sense strand. The $5^{\prime}$ end of the DNA fragments derived from these oligonucleotides were in-frame with the GST of PGEX2T and the $3^{\prime}$ ends were out of frame, resulting in amino acid residues NSS at the carboxyl terminus of the GST/peptide fusion proteins. The synthetic oligonucleotides were phosphorylated using T4 polynucleotide kinase under conditions recommended by the manufacturer (New England Biolabs). The sense and anti-sense strands were annealed after phosphorylation by boiling for 2 min and then cooling down slowly to room temperature (about $\left.25^{\circ} \mathrm{C}\right)$. The DNA fragment was cloned into the pGEX-2T vector.

The human Crk-I gene was cloned from HeLa cDNA by PCR using the $5^{\prime}$ primer AAGGATAGGCGGCCGCCACCATGGTTGGATACCCCTACGACGTCCCCGACTACGCCGGAGTTATGGCGGGCAACTTGGACTCG (where the underlined segment encodes the HA epitope and the $A T G$ indicates the natural start codon/ and the $3^{\prime}$ primer AAGGATAGGCGGCCGCACTCAGCTGAAGTCCTCATCGGGATTCTG. The PCR product was digested with NotI and cloned into the NotI site of pGDN, a derivative of the retroviral vector pGD (Daley et al. 1990). Crk-I cDNA was confirmed by sequence analysis. The
Crk-I cDNA in right orientation in pGDN vector was selected and used in studies.

The pGD/abl ${ }^{\mathrm{mu1}}$ was constructed by first subcloning BamHI $(744$, nucleotide number according to murine type IV c-ab1) and XhoI (2285) from $\triangle B S-F$ (Mayer and Baltimore 1994) into pBS (Strategene). The PstI (1645) to PstI (1681) segment (encoding LQAPELPTKTRTC) was replaced by a linker encoding LQAEFRTC. The BamHI and NarI fragment containing the mutation was cloned back to $\triangle B S-F$ and then the NotI fragment containing the $c-a b 1^{\text {mu1 }}$-coding sequences was cloned into pGDN. The pGD/abl $1^{\mathrm{mu} 2}$ was constructed by replacing PLLPRK (596-601, amino acid number in type IV c-Abl) into ID by oligo-directed PCR mutagenesis as described (Higuchi 1990). All of the mutations were confirmed by sequence analysis.

\section{The two-hybrid screen}

A genetic screen using the two-hybrid system was performed as described (Zervos et al. 1993). The bait plasmid pEG/ablC' was transformed into yeast strain EGY48 with a reporter plasmid pSH18-34 that contains the LexAop-LEU2 reporter gene. This strain was transformed with the HeLa interaction library (Zervos et al. 1993). Yeast transformation was performed by the lithium acetate method (Ausubel et al. 1990) except that $10 \%$ dimethylsulfoxide (DMSO) was included during $42^{\circ} \mathrm{C}$ heat shock. Ten million primary library transformants were amplified, of which 5 million were screened. The candidate $\mathrm{AblC}^{\prime}$ interacting clones were selected as meeting the following criteria: (1) They grew on $\mathrm{Ura}^{-} \mathrm{His}^{-} \mathrm{Trp}^{-} \mathrm{Leu}^{-}$-galactose plates; and (2) they turned blue on Ura ${ }^{-} \mathrm{His}^{-} \mathrm{Trp}^{-} \mathrm{X}$-gal-galactose plates but not on $\mathrm{Ura}^{-} \mathrm{His}^{-} \mathrm{Trp}^{-} \mathrm{X}$-gal-glucose plates. Plasmids from the candidate yeast strains were isolated (Hoffman and Winston 1987), and the library plasmids were selected through KC8 cells. To test whether the library cDNAs truly encoded proteins that interacted specifically with $\mathrm{AblC}^{\prime}$, the library plasmids were retransformed back into yeast with either EG202/AblC' or EG202. Sequencing of the interacting clones was performed using Sequenase according to the manufacturer's directions (U.S. Biochemical).

\section{Filter-binding assay}

To examine $\mathrm{SH} 3$ binding in vitro, a filter-binding assay was performed as described (Ren et al. 1993). GST/CrkI-SH3 was constructed by subcloning the EcoRI-XhoI cDNA fragment encoding the c-Abl-interacting partial Crk-I protein from the pJG45 vector in-frame into pGEX-1ZT vector. The fusion protein was purified using glutathione-agarose beads and biotinylated as described (Mayer et al. 1991). The GST/Abl-SH3, GST/ Src-SH3, GST/N-Src-SH3, and GST/Crk-SH3 probes were prepared as described (Cicchetti et al. 1992). The GST/Grb2, GST/ GrbN2, GST/Grb2C, and GST/Nck fusion proteins were generous gifts from J. Schlessinger (New York University). Biotinylation of these proteins was performed as described (Mayer et al. 1991).

\section{Transfection}

Calcium phosphate transfection was performed as described (Pear et al. 1993). $293 \mathrm{~T}$ cells $\left(1.5 \times 10^{6}\right)$ were seeded in $60-\mathrm{mm}$ plastic cell culture plates 1 day before use. Each plate was treated with 0.5 or $1 \mathrm{ml}$ of a DNA-calcium phosphate coprecipitate containing $3 \mu \mathrm{g}$ each of the plasmid DNAs. After $18 \mathrm{hr}$ of incubation at $37^{\circ} \mathrm{C}$, the medium was replaced and incubation was continued for $24 \mathrm{hr}$. 


\section{Immunoprecipitation}

Cells $\left(1 \times 10^{7}\right)$ were washed once in ice-cold phosphate-buffered saline (PBS) containing $1 \mathrm{~mm}$ sodium orthovanadate and then lysed in $1 \mathrm{ml}$ of ice-cold lysis buffer (50 mM HEPES at $\mathrm{pH} 7.4$, $150 \mathrm{~mm} \mathrm{NaCl}, 10 \%$ glycerol, $1 \%$ Triton X-100, 1 mM EGTA, 1.5 $\mathrm{mM} \mathrm{MgCl}_{2}, 10 \mathrm{mM} \mathrm{NaF}, 1 \mathrm{~mm}$ sodium orthovanadate, $1 \mathrm{~mm}$ freshly made phenylmethylsulfonyl fluoride, $10 \mu \mathrm{g} / \mathrm{ml}$ of aprotinin, $10 \mu \mathrm{g} / \mathrm{ml}$ of leupeptin). The cell debris was removed by centrifugation at $14,000 \mathrm{rpm}$ in Eppendorf centrifuge for $10 \mathrm{~min}$ at $4^{\circ} \mathrm{C}$. The cell lysate was incubated with $5 \mu$ l of normal rabbit serum and $25 \mu$ l of protein G-plus/protein A-agarose (Oncogene Science) for $1 \mathrm{hr}$ and then clarified by centrifugation at 14,000 $\mathrm{rpm}$ in Eppendorf centrifuge for $2 \mathrm{~min}$. The clarified cell lysate was incubated with $5 \mu \mathrm{g}$ of the appropriate monoclonal antibody or $5 \mu \mathrm{l}$ of the polyclonal antiserum at $4^{\circ} \mathrm{C}$ for $2-5 \mathrm{hr}$. The immunocomplexes were then collected after the addition of 25 $\mu \mathrm{l}$ of protein G-plus/protein A-agarose and incubation at $4^{\circ} \mathrm{C}$ for $30 \mathrm{~min}$. The pellets of agarose beads were washed three times with $1 \mathrm{ml}$ of lysis buffer and then subjected to kinase reaction or immunoblotting.

\section{Kinase reaction}

The kinase reaction was carried out as described (Konopka et al. 1984). The pellets of agarose beads obtained from immunoprecipitation described above were transferred to a fresh Eppendorf tube and washed twice with $1 \mathrm{ml}$ of kinase buffer $(20 \mathrm{~mm}$ HEPES at $\mathrm{pH} 7.4,5 \mathrm{~mm} \mathrm{MgCl}{ }_{2}$ ). The kinase reaction was carried out in $100 \mu \mathrm{l}$ of kinase buffer containing $10 \mu \mathrm{M}$ ATP and $0.2 \mu \mathrm{l}$ of $\left[\gamma^{-32} \mathrm{P}\right] \mathrm{ATP}$ (7000 Ci/mmole) (ICN) at $30^{\circ} \mathrm{C}$ for $30 \mathrm{~min}$. The pellets of agarose beads were washed with PBS twice. The bound proteins were eluted in Laemmli sample buffer at $95^{\circ} \mathrm{C}$ for 5 min, and then the phosphorylated proteins were analyzed by SDS-PAGE and autoradiography.

\section{Western blot analysis}

Cells were lysed as described above. The cell extracts or antiHA immunoprecipitates were boiled in Laemmli sample buffer, electrophoretically separated on $10 \%$ SDS-polyacrylamide gels and transferred to nitrocellulose. Filters were blocked in $10 \mathrm{~mm}$ Tris- $\mathrm{HCl}$ at $\mathrm{pH} 8.0 / 0.9 \% \mathrm{NaCl} / 0.05$ Tween 20 (TBST buffer) plus $2 \%$ nonfat dry milk. Filters were blotted with $1 \mu \mathrm{g} / \mathrm{ml}$ of anti-HA antibody or anti-Abl monoclonal antibody in TBST/ milk buffer at room temperature for $2 \mathrm{hr}$. After wash in TBST, filters were incubated with anti-mouse IgG2b- or IgG-conjugated horseradish peroxidase at a dilution of 1:2000 in TBST buffer at room temperature for $1 \mathrm{hr}$. Filters were then washed and developed with ECL (Amersham), as described by the manufacturer.

\section{Cell metabolic labeling and phosphoamino acid analysis}

After $48 \mathrm{hr}$ of transfection, 293 cell monolayers were washed twice with phosphate-free DMEM (GIBCO) and incubated in phosphate-free DMEM containing $10 \%$ dialyzed fetal bovine serum (GIBCO) for $2 \mathrm{hr}$. Cells were washed twice with phosphate-free DMEM again and incubated in phosphate-free DMEM containing $10 \%$ dialyzed fetal bovine serum and ${ }^{32} \mathrm{P}_{\mathrm{i}}$ (NEN, $1 \mathrm{mCi} / \mathrm{ml}$ per $60-\mathrm{mm}$ dish) for $2 \mathrm{hr}$. The ${ }^{32} \mathrm{P}$-labeled cells were then washed once with ice-cold PBS and harvested, lysed, and immunoprecipitated with anti-HA antibody as described above. The immunoprecipitates were separated electrophoretically in SDS-PAGE and detected by autoradiography.

Phosphoamino acid analyses were performed as described
(Nairn and Greengard 1987; Li et al. 1992). Briefly, phosphorylated protein bands were excised from dried SDS gels, rehydrated in $50 \mathrm{mM} \mathrm{NH}_{4} \mathrm{HCO}_{3}$, minced, and boiled in $0.1 \%$ SDS/ $5 \% \beta$-mercaptoethanol for $5 \mathrm{~min}$. The mixture was incubated at $37^{\circ} \mathrm{C}$ with agitation overnight. The gel debris was removed by centrifugation. The supernatants were mixed with $50 \mu \mathrm{g}$ of BSA and precipitated in $15 \%$ trichloroacetic acid on ice for $90 \mathrm{~min}$. The precipitates were washed twice with cold acetone. The protein was hydrolyzed in $6 \mathrm{~N} \mathrm{HCl}$ at $110^{\circ} \mathrm{C}$ for $1 \mathrm{hr}$. Hydrolysis was stopped by adding $\mathrm{I} \mathrm{ml}$ of $\mathrm{H}_{2} \mathrm{O}$ and drying in a Speed-Vac. The sample was washed with $\mathrm{H}_{2} \mathrm{O}$, dried twice, and then dissolved in $5 \mu \mathrm{l}$ of electrophoresis buffer ( $\mathrm{pH}$ 1.9). Phosphoamino acid standards $(2 \mu \mathrm{g}$, phosphoserine, phosphothreonine, and phosphotyrosine) and $1 \mu \mathrm{l}$ of $0.08 \%$ phenol red were added into the sample. The mixture was spotted on thin-layer chromatography (TLC), cellulose without fluorescent indicator (Kodak). The wetted TLC plate was run in $\mathrm{pH} 1.9$ buffer at $500 \mathrm{~V}$ for $1 \mathrm{hr}$ and then transferred to $\mathrm{pH} 3.5$ buffer and run at $500 \mathrm{~V}$ for $1-1.5 \mathrm{hr}$. The TLC plate was then stained with $1 \%$ ninhydrine to show phosphoamino acid spots and exposed to X-ray film with an intensifying screen at $-70^{\circ} \mathrm{C}$ for 3 days.

\section{Acknowledgments}

We thank Dr. R. Brent for kindly providing the yeast two hybrid cloning system, Drs. L. Ron, R. Finley, and E. Golemis for technical advice. Drs. W. Li, A.G. Batzer, and J. Schlessinger for kindly providing the GST-Nck, GST-Grb2, GST/Grb2-N2, and GST/Grb2-2C fusion proteins. We are grateful to Drs. B. Mayer, K. Saksela, G. Cheng, W. Pear, K. Alexandropoulos and other members of D.B.'s laboratory for technical assistance and helpful discussions. This work was supported by a postdoctoral fellowship from the Cancer Research Institute (R.R.), Leukemia Society of America (Z.Y.), and U.S. Public Health Service grant (CA 51462) to D.B.

The publication costs of this article were defrayed in part by payment of page charges. This article must therefore be hereby marked "advertisement" in accordance with 18 USC section 1734 solely to indicate this fact.

\section{References}

Ausubel, F.M., R. Brent, R.E. Kingston, D.D. Moore, J.G. Seidman, J.A. Smith, and K. Struhl. 1990. Current protocols in molecular biology. John Wiley and Sons, New York.

Bar-Sagi, D., D. Rotin, A. Batzer, V. Mandiyan, and J. Schlessinger. 1993. SH3 domains direct cellular localization of signaling molecules. Cell 74: 83-91.

Ben-Neriah, Y., A. Bernards, M. Paskind, G.Q. Daley, and D. Baltimore. 1986. Alternative 5' exons in c-abl mRNA. Cell 44: $577-586$.

Booker, G.W., I. Gout, A.K. Downing, P.C. Driscoll, J. Boyd, M.D. Waterfield, and I.D. Campbell. 1993. Solution structure and ligand-binding site of the SH3 domain of the p85 $\alpha$ subunit pf phosphotidylinositol 3-kinase. Cell 73: 813-822.

Chou, M.M., J.E. Fajardo, and H. Hanafusa. 1992. The SH2- and SH3-containing Nck protein transformsmammalian fibroblasts in the absence of elevated phosphotyrosine levels. Mol. Cell. Biol. 12: 5834-5842.

Cicchetti, P., B.J. Mayer, G. Thiel, and D. Baltimore. 1992. Identification of a protein that binds to the $\mathrm{SH} 3$ region of $\mathrm{Abl}$ and is similar to Bcr and GAP-rho. Science 257: 803-806.

Clark, S.G., M.J. Stern, and H.R. Horvitz. 1992. C. elegans cellsignalling gene sem -5 encodes a protein with $\mathrm{SH} 2$ and $\mathrm{SH} 3$ domains. Nature 356: 340-344. 
Crews, C.M. and R.L. Erikson. 1993. Extracellular signals and reversible protein phosphorylation: What to Mek of it all. Cell 74: 215-217.

Daley, G.Q. and Y. Ben-Neriah. 1991. Implicating the Bcr-Abl gene on the pathogenesis of philadelphia chromosome positive human leukemia. Adv. Cancer Res. 57: 151-184.

Daley, G.Q., R.A. Van Etten, and D. Baltimore. 1990. Induction of chronic myelogenous leukemia in mice by the P210 bcr/ abl gene of the philadelphia chromosome. Science 247: 824830.

Egan, S.E., B.W. Giddings, M.W. Brooks, L. Buday, A.M. Sizeland, and R.A. Weinberg. 1993. Association of Sos Ras exchane protein with Grb2 is implicated in tyrosine kinase signal transduction and transformation. Nature 363: 45-51.

Fields, S. and O. Song. 1989. A novel genetic system to detect protein-protein interaction. Nature 340: 245-246.

Foulkes, J.G., B. Mathey-Prevot, B.C. Guild, R. Prywes, and D. Baltimore. 1985. A comparison of the protein-tyrosine kinases encoded by Abelson murine leukemia virus and Rous sarcoma virus. Cancer Cells 3: 329-337.

Frackelton, A.R., Jr. 1985. Characterization of phosphotyrosyl proteins in cells transformed by abelson murine leukemia virus: Use of a monoclonal antibody to phosphotyrosine. Cancer Cells 3: 339-345.

Franz, W.M., P. Berger, and J.Y.J. Wang. 1989. Deletion of an $N$-terminal regulatory domain of the c- $a b l$ tyrosine kinase activates its oncogenic potential. EMBO $/$. 8: 137-147.

Goga, A., J. Mclaughlin, A. Pendergast, K. Parmar, A. Muller, N. Rosenberg, and O. Witte. 1993. Oncogenic activation of c-Abl by mutation within its last exon. Mol. Cell. Biol. 13: $4967-4975$.

Gout, I., R. Dhand, I.D. Hiles, M.J. Fry, G. Panayotou, P. Das, O. Truong, N.F. Totty, J. Hsuan, G.W. Booker, I.D. Campbell, and M.D. Waterfield. 1993. The GTPase dynamin binds to and is activated by a subset of SH3 domains. Cell 75: 25-36.

Henkemeyer, M., S.R. West, F.B. Gertier, and F.M. Hoffman. 1990. A novel tyrosine kinase-independant function of Drosophila Abl correlates with proper subcellular localization. Cell 65: 451-464.

Higuchi, R. 1990. Recombinant PCR. In PCR protocols: $A$ guide to methods and applications. (ed. M.A. Inns, D.H. Gelfand, J.J. Sninsky, and T.J. White), pp. 177-183. Academic Press, San Diego CA.

Hoffman, C.S. and F. Winston. 1987. A ten minute DNA preparation from yeast efficiently releases autonomus plasmids for transformation of E. coli. Gene 57: 267-272.

Jackson, P. and D. Baltimore. 1989. N-terminal mutations activate the leukemogenic potential of the myristoylated form of c-abl. EMBO J. 8: 449-456.

Jackson, P., D. Baltimore, and D. Picard. 1993a. Hormone-conditional transformation by fusion proteins of $\mathrm{c}-\mathrm{Abl}$ and its transforming variants. $E M B O$ I. 12: 2809-2819.

Jackson, P.K., M. Paskind, and D. Baltimore. 1993b. Mutation of a phenylalanine conserved in $\mathrm{SH} 3$-containing tyrosine kinases activates the transforming ability of c-Abl. Oncogene 8: 1943-1956.

Kohda, D., H. Hatanaka, M. Odaka, V. Mandiyan, A. Ullrich, J. Schlessinger, and F. Inagaki. 1993. Solution structure of the SH3 domain of phospholipase C- $\gamma$. Cell 72: 953-960.

Konopka, J.B., R.L. Davis, S.M. Watanabe, A.S. Ponticelli, L. Schiff-Maker, N. Rosenberg, and O.N. Witte. 1984. Only site-directed antibodies reactive with the highly conserved src-homologous region of the $\mathrm{v}$ - $a b l$ protein neutralize kinase activity. /. Virol. 51: 223-232.

Koyama, S., H. Yu, D.C. Dalgarno, T.B. Shin, L.D. Zydowsky, and S.L. Schreiber. 1993. Structure of the PI3K SH3 domain and analysis of the SH3 family. Cell 72: 945-952.

Kruh, G.D., C.R. King, M.H. Kraus, N.C. Popescu, S.C. Amsbaugh, W.O. McBride, and S.A. Aaronson. 1986. A novel human gene closely related to the $a b l$ proto-oncogene. Science 234: 1545-1548.

Lehmann, J.M., G. Riethmuller, and J. Johnson. 1990. Nck, a melanoma cDNA encoding a cytoplasmic protein consisting of the src homology units $\mathrm{SH} 2$ and SH3. Nucleic Acids Res. 18: 1048.

Li, N., A. Batzer, R. Daly, V. Yajnik, E. Skolnik, P. Chardin, D. Bar-Sagi, B. Margolis, and J. Schlessinger. 1993. Guaninenucleotide-releasing factor hSos 1 binds to Grb2 and links receptor tyrosine kinases to Ras signalling. Nature 363: 8588.

Li, W., P. Hu, E.Y. Skolnik, A. Ullrich, and J. Schlessinger. 1992. The $\mathrm{SH} 2$ and $\mathrm{SH} 3$ domain-containing Nck protein is oncogenic and a common target for phosphorylation by different surface receptors. Mol. Cell. Biol. 12: 5824-5833.

Liu, X., L.E.M. Marengere, C.A. Koch, and T. Pawson. 1993. The v-Src SH3 domain binds phosphatidyinositol 3'-kinase. Mol. Cell. Biol. 13: 5225-5232.

Lowenstein, E.J., R.J. Daly, A. Batzer, D. Bar-Sagi, and J. Schlessinger. 1992. The SH2 and SH3 domains containing protein GRB2 links receptor tyrosine kinases to ras signaling. Cell 70: $431-442$.

Matsuda, M., B.J. Mayer, Y. Fukui, and H. Hanafusa. 1990. Binding of transforming protein, $\mathrm{P} 47^{\text {gag-crk }}$, to a broad range of phosphotyrosine-containing proteins. Science 248: 15371539.

Matsuda, M., S. Tanaka, S. Nagata, A. Kojima, T. Kurata, and M. Shibuya. 1992. Two species of human CRK cDNA encode proteins with distinct biological activities. Mol. Cell. Biol. 12: 3482-3489.

Matuoka, K., M. Shibata, A. Yamakawa, and T. Takenawa. 1992. Cloning of ASH, aubiquitous protein composed of one Src homology region (SH) 2 and two $\mathrm{SH} 3$ domains, from human and rat cDNA libraries. Proc. Natl. Acad. Sci. 89: 9015-9019.

Mayer, B. and D. Baltimore. 1993. Signalling through $\mathrm{SH} 2$ and SH3 domains. Trends Cell Biol. 3: 8-13.

. 1994. Mutagenic analysis of the roles of SH2 and SH3 domains in regulation of the Abl tyrosine kinase. Mol. Cell. Biol. (in press).

Mayer, B.J. and H. Hanafusa. 1990a. Association of the v-crk oncogene product with phosphotyrosine-containing proteins and protein kinase activity. Proc. Natl. Acad. Sci. 87: 26382642 .

- 1990b. Mutagenic analysis of the v-crk oncogene: requirement for $\mathrm{SH} 2$ and $\mathrm{SH} 3$ domains and correlation between increased cellular phosphotyrosine and transformation. J. Virol. 64: 3581-3589.

Mayer, B.J., M. Hamaguchi, and H. Hanafusa. 1988. A novel viral oncogene with structural similarity to phospholipase C. Nature 332: 272-275.

Mayer, B.J., P.K. Jackson, and D. Baltimore. 1991. The noncatalytic src homology region 2 segment of $a b l$ tyrosine kinase binds to tyrosine-phosphorylated cellular proteins with high affinity. Proc. Natl. Acad. Sci. 88: 627-631.

McCormick, F. 1993. How receptors turn Ras on. Nature 363: 15-16.

McWhirter, J.R. and J.Y.J. Wang. 1991. Activation of tyrosine kinase and microfilament binding functions of $\mathrm{c}-\mathrm{Abl}$ by $\mathrm{Bcr}$ sequences in Bcr/Abl fusion proteins. Mol. Cell. Biol. 11: 1553-1565.

Meisenhelder, I. and T. Hunter. 1992. The SH2/SH3 domaincontaining protein Nck is recognized by certain anti phos- 
pholipase $\mathrm{C} \gamma \mathrm{I}$ monoclonal antibodies, and its phosphorylation on tyrosine is stimulated by pletelet-derived growth factor or epidermal growth factor treatment. Mol. Cell. Biol. 12: 5843-5856.

Muller, A.J., J.C. Young, A. Pendergast, M. Pondel, N.R. Landau, D.R. Littman, and O.N. Witte. 1991. BCR first exon sequences specifically activate the bcr/abl tyrosine kinase oncogene of Philadelphia chromosome-positive human leukemias. Mol. Cell. Biol. 11: 1785-1792.

Musacchio, A., M. Noble, R. Pouptit, R. Wierenga, and M. Saraste. 1992. Crystal structure of a Src-homology 3 (SH3) domain. Nature 359: 851-855.

Nairn, A.C. and P. Greengard. 1987. Purification and characterization of $\mathrm{Ca}^{2+} /$ calmodulin-dependent protein kinase I from bovine brain. J. Biol. Chem. 262: 7273-7281.

Noble, M.E.M., A. Musacchio, M. Saraste, S.A. Courtneidge, and R.K. Wierenga. 1993. Crystal structure of the SH3 domain in human Fyn; comparison of the three-dimensional structures of $\mathrm{SH} 3$ domains in tyrosine kinases and spectrin. EMBO \%. 12: 2617-2624.

Park, D.J. and S.G. Rhee. 1992. Phosphorylation of Nck in response to a variety of receptors, phorbol myristate acetate, and cyclic AMP. Mol. Cell. Biol. 12: 5816-5823.

Pawson, T. 1988. Non-catalytic domains of cytoplasmic protein-tyrosine kinases: regulatory elements in signal transduction. Oncogene 3: 491-495.

Pawson, T. and G. Gish. 1992. SH2 and SH3 domains: From structure to function. Cell 71: 359-362.

Pear, W.S., G.P. Nolan, M.L. Scott, and D. Baltimore. 1993. Production of high-titer helper-free retroviruses by transient transfection. Proc. Natl. Acad. Sci. 90: 8392-8396.

Pendergast, A.M., L.A. Quilliam, L.D. Cripe, C.H. Bassing, Z. Dai, N. Li, A. Batzer, K.M. Rabun, C.J. Der, J. Schlessinger, and M. Gishizky. 1993. BCR-ABL-induced oncogenesis is mediated by direct interaction with the $\mathrm{SH} 2$ domain of the Grb-2 adaptor protein. Cell 75: 175-185.

Ren, R., B.J. Mayer, P. Cicchetti, and D. Baltimore. 1993. Identification of a 10-amino acid proline-rich $\mathrm{SH} 3$ binding site. Science 259: 1157-1161.

Rosenberg, N. and O.N. Witte. 1988. The viral and cellular forms of the Abelson (abl) oncogene. In Advances in virus research, pp.39-81. Academic Press, New York.

Rozakis-Adcock, M., R. Fernley, J. Wade, T. Pawson, and D. Bowtell. 1993. The SH2 and SH3 domains of mammalian Grb2 couple the EGF receptor to the Ras activator mSos1. Nature 363: 83-85.

Schwartzberg, P.L., A.M. Stall, J.D. Hardin, K.S. Bowdish, T. Humaran, S. Boast, M.L. Harbison, E.J. Robertson, and S.P. Goff. 1991. Mice homozygous for the ablml mutation show poor viability and depletion of selected $B$ and $T$ cell populations. Cell 65: 1165-1175.

Simon, M.A., G.S. Dodson, and G.M. Rubin. 1993. An SH3-SH3$\mathrm{SH} 3$ protein is required for $\mathrm{p} 21^{\text {Ras }}$ activation and bind to sevenless and Sos proteins in vitro. Cell 73: 169-177.

Tanaka, S., S. Hattori, T. Kurata, K. Nagashima, Y. Fukui, S. Nakamura, and M. Matsuda. 1993. Both the SH2 and SH3 domain of human CRK protein are required for neuronal differentiation of PC 12 cells. Mol. Cell. Biol. 13: 4409-4415.

Tsuchie, H., C.H.W. Chang, M. Yoshida, and P. Vogt. 1989. A newly isolated avian sarcoma virus, ASV-1, carries the crk oncogene. Oncogene 4: 1281-1284.

Tybulewicz, V.L.J., C.E. Crawford, P.K. Jackson, R.T. Bronson, and R.C. Mulligan. 1991. Neonatal lethality and lymphopenia in mice with a homozygous disruption of the $c$ - $a b l$ protooncogene. Cell 65: 1153-1163.

Van Aelst, L., M. Barr, S. Marcus, A. Polverino, and M. Wigler.
1993. Complex formation between RAS and RAF and other protein kinases. Proc. Natl. Acad. Sci. 90: 6213-6217.

Van Etten, R.A., P. Jackson, and D. Baltimore. 1989. The mouse type IV c-abl gene product is a nuclear protein, and activation of transforming ability is associated with cytoplasmic localization. Cell 58: 669-678.

Van Etten, R.A., P.K. Jackson, D. Baltimore, M. Sanders, P.T. Matsudaira, and P.A. Janmey. 1993. The C-terminus of the c-Abl tyrosine kinase contains distinct F- and G-actin binding domains with bundling activity. I. Cell. Biol. 124: 325340.

Wang, J.Y.J. 1993. Abl tyrosine kinase in signal transduction and cell-cycle regulation. Curr. Opin. Genet. Dev. 3: 35-43.

Wang, J.Y.J., C. Queen, and D. Baltimore. 1982. Expression of an Abelson murine leukemia virus-encoded protein in Escherichia coli causes extensive phosphorylation of tyrosine residues. J. Biol. Chem. 257: 13181-13184.

Weng, Z., J.A. Taylor, C.E. Turner, J.S. Brugge, and C. SeidelDugan. 1993. detection of Src homology 3-binding proteins, including paxillin, in normal and v-Src-transformed Balb/c 3T3 cells. J. Biol. Chem. 268: 14956-14963.

Yu, H., M.K. Rosen, T.B. Sin, C. Seidel-Dugan, J.S. Brugge, and S. Schreiber. L. 1992. Solution structure of the SH3 domain of src and identification of its ligand binding site. Science 258: 1665-1668.

Zervos, A.S., J. Gyuris, and R. Brent. 1993. Mxil, a protein that specifically interacts with Max to bind Myc-Max recognition sites. Cell 72: 223-232. 


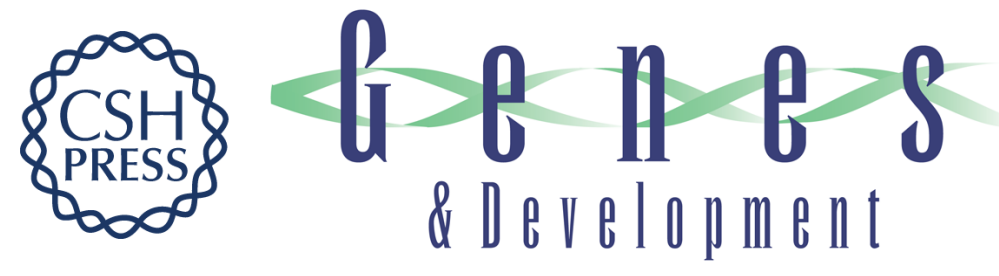

\section{Abl protein-tyrosine kinase selects the Crk adapter as a substrate using SH3-binding sites.}

R Ren, Z S Ye and D Baltimore

Genes Dev. 1994, 8:

Access the most recent version at doi:10.1101/gad.8.7.783

References This article cites 64 articles, 25 of which can be accessed free at:

http://genesdev.cshlp.org/content/8/7/783.full.html\#ref-list-1

License

Email Alerting

Service

Receive free email alerts when new articles cite this article - sign up in the box at the top right corner of the article or click here.

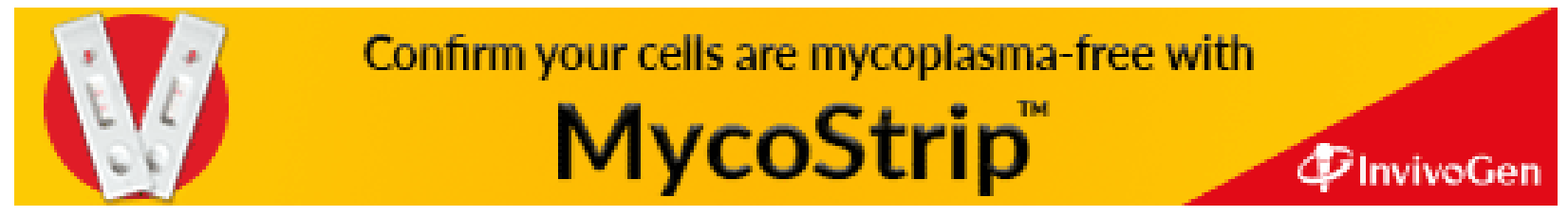

